\title{
Experimental Study of Behavior of Castellated Beam with Diamond Shape Opening Under Lateral -Torsional Buckling
}

\author{
Guruprasad. D. Kulkarni ${ }^{1}$ \\ ${ }^{1} \mathrm{PG}$ Scholar, \\ Dept. of Civil Engineering, \\ Rajarambapu Institute of Technology, \\ Maharashtra, India
}

\author{
Rahul.D. Patil ${ }^{2}$ \\ ${ }^{2}$ Asst.Professor, \\ Dept. of Civil Engineering, \\ Rajarambapu Institute of Technology, \\ Maharashtra, India
}

\begin{abstract}
This project discusses optimization of the depth of opening i.e. depth of opening of castellated steel beam containing diamond openings. Optimization of opening of diamond shape was performed using finite element method (FEM). The results of FEM analysis are verified by implementing laboratory testing of $150 \mathrm{~mm}$ height castellated beam specimen. All the castellated beam specimens were modified from $100 \mathrm{~mm}$ I beam. Optimum results from FEM analysis was a castellated beam with diamond openings having opening size overall depth with $\mathrm{D} / \mathrm{D0}$ ratio 1.25 and D/D0 1.75. From laboratory testing results and FEM analysis it is observed that, the deflection obtained from FEM result is 0.900 millimetre. While deflection from experiment results is 0.933 millimetre. Percentage variation in above case is almost negligible, that is 3.66 percent.
\end{abstract}

Keywords: Optimization, Castellated beam, Diamond openings, finite element analysis.

\section{INTRODUCTION}

This project work is mainly focused on parametric study of perforated web beams. The main aim of work is to optimize the sizes of openings provided in the beam. In this chapter some introductory information about perforated web beams are summarized.

\section{History of perforated web beam}

Castellated name come from the Latin word whose meaning is to structurally fortify. Before castellated beams, I-beams were used in construction because they are strong and solid way of supporting houses and other industrial structures. Castellated beams were developed as structural channels to increase the beam's depth of parent I-beam and strength without adding additional material causing no change in weight. Since the 1950 , because of shortage of steel and increase in cost of steel, castellated beams get started to be used in the construction. Castellated beams were advanced in Europe to overcome the steel shortages and high cost of steel. Castellated beams are the beams having different geometrical shape perforations in the web of beam. The different shapes such as hexagonal, circular, rectangular, diamond, sinusoidal etc. are used in castellated beams. These shapes are constructed with the help of computer controlled cutting torch to cut the section according to given geometry.

\section{Types of castellated beam}

Depending upon opening there are different types of castellated beams. Following are the different types of castellated beams. Circular opening, Sinusoidal opening, diamond opening.

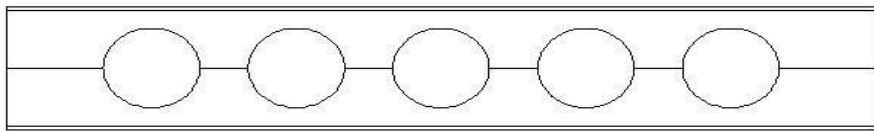

Figure: Castellated Beam with circular opening

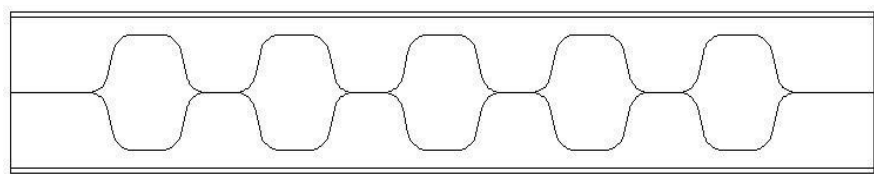

Figure: Castellated Beam with Sinusoidal opening

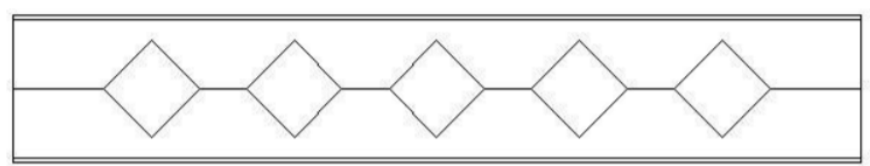

Figure: Castellated Beam with diamond opening

\section{Literature Review}

The study on castellated beam based on various size and shape of opening, varying Centre to Centre distance between two openings was studied in Various literatures in addition to that the behavior of castellated beam for flexural was also studied. But the very little study on effect of lateral torsion on castellated beam

\section{Objective}

1. To study buckling behavior of castellated beam under lateral torsion using Abaqus software.

2. To validate Abaqus software results experimentally.

3. To investigate effect of torsion on diamond shaped castellated beam by taking various depth of opening to depth of beam ratio.

4.To optimize position of depth of opening to depth of beam ratio and suggest guideline for the ratio. 


\section{Parametric Study}

In this chapter, parametric study is explained. Also, the details of terminologies of castellated beam and the guidelines given by euro code for perforation are given. The parametric study of castellated beam for various combinations such as size of opening ie depth of opening and length of opening are presented in this chapter.
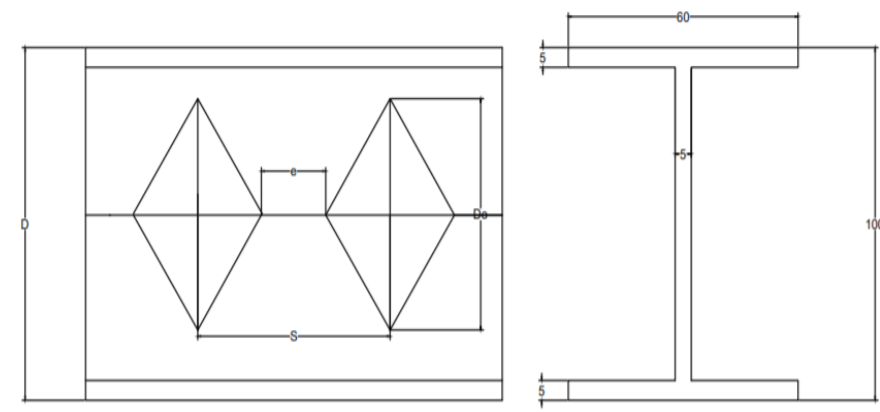

Figure : Typical castellated beam with its Cross Section

\section{Terminology in castellated beam}

Before going to analysis of castellated beam it is important to understand few basic terminologies used in the geometry of castellated beam, these terms are illustrated in the following Figure 3.1 Where,

Do $=$ Depth of opening provided

$\mathrm{D}=$ Overall depth of the opening

$\mathrm{S}=$ Centre to Centre spacing between the two opening

$\mathrm{e}=$ Clear distance between two opening

$\mathrm{b}=$ Width of flange of I beam

$\mathrm{tf}=$ Thickness of flange of I beam

$\mathrm{tw}=$ Thickness of web of I beam

\section{Detailed methodology adopted}

The procedure used in the project was divided into three steps. First step is related with software analysis in computer. Method used for analysis of castellated beam with diamond opening was finite element method. Deflection was computed from software analysis which is then verified by performing the second step which is laboratory tested of castellated beam. In third step after comparing the result parametric study was conducted for optimization of ratio.

\section{Method of analysis}

Abaqus 6.14 CAE was used to analyses the castellated beam with diamond opening. The finite element model is linear for deformation and material behavior, material properties for steel are modulus of elasticity $\mathrm{E}=200 \mathrm{GPa}$ and poison's ratio equal to 0.3 . The beam examined in the study are simply supported at the end and loaded with two-point loads at length by three distances.

\begin{tabular}{|l|l|l|l|l|l|l|}
\hline $\begin{array}{l}\text { Sr. } \\
\text { No }\end{array}$ & $\mathbf{D}_{\mathbf{0}}$ & $\mathbf{D}$ & $\mathbf{D} / \mathbf{D}_{\mathbf{0}}$ & $\mathbf{S}^{\mathbf{B}} \mathbf{\mathbf { 0 } _ { \mathbf { 0 } }}$ & $\mathbf{S}$ & $\mathbf{e}$ \\
\hline 1 & 120 & 150 & 1.25 & 1.29 & 154.8 & 45.6 \\
\hline 2 & 111.11 & 150 & 1.35 & 1.29 & 143.33 & 44.44 \\
\hline 3 & 103.45 & 150 & 1.45 & 1.29 & 133.45 & 41.38 \\
\hline 4 & 96.77 & 150 & 1.55 & 1.29 & 124.83 & 38.70 \\
\hline 5 & 90.90 & 150 & 1.65 & 1.29 & 117.26 & 36.36 \\
\hline 6 & 85.71 & 150 & 1.75 & 1.29 & 110.56 & 34.28 \\
\hline
\end{tabular}

Table: Parameters considered for Diamond shaped opening

\section{Fabrication of castellated beam}

Castellated beam has been derived from the I beam having depth $100 \mathrm{~mm}$. the diamond pattern has been created by using machine i.e. profile cutter. For that first the detailed drawing has been made. In case of profile cutting, cutting profile has to draw on software with the real scale .

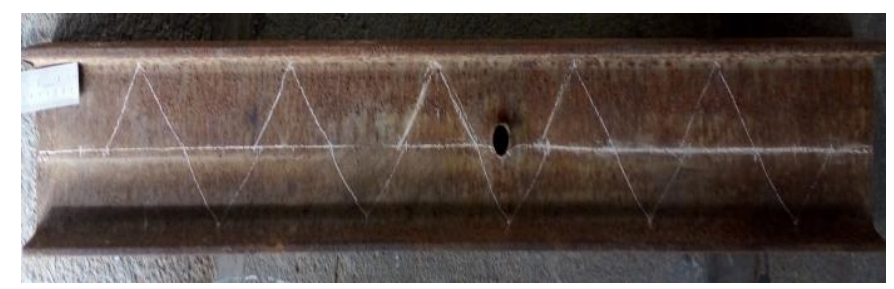

Figure 4.1: Cut profile for cutting diamond opening

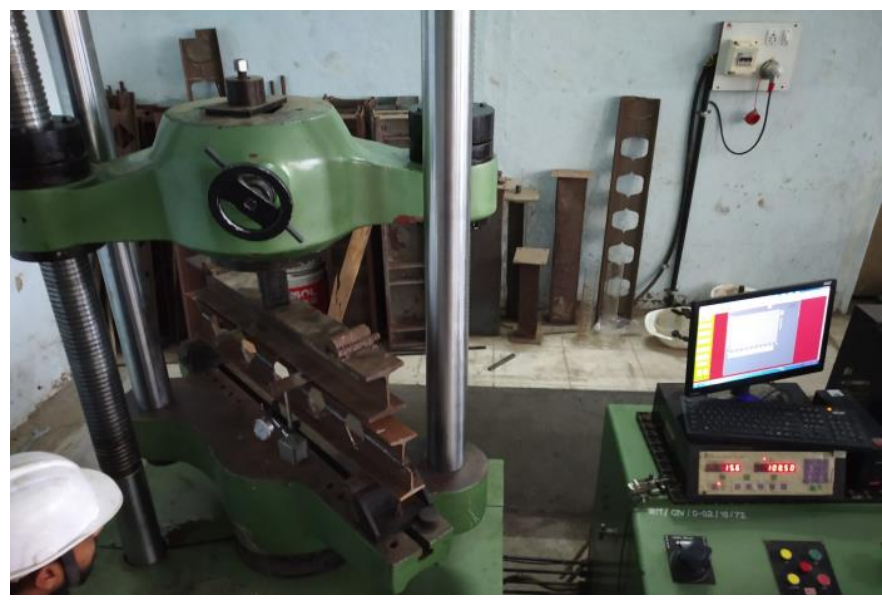

Figure: Test Set -up

\section{Modelling and analysis}

In this chapter, finite element analysis of castellated beam having diamond opening in Abaqus software is explained. Important points in FEA are discussed and steps for modelling are described in brief 

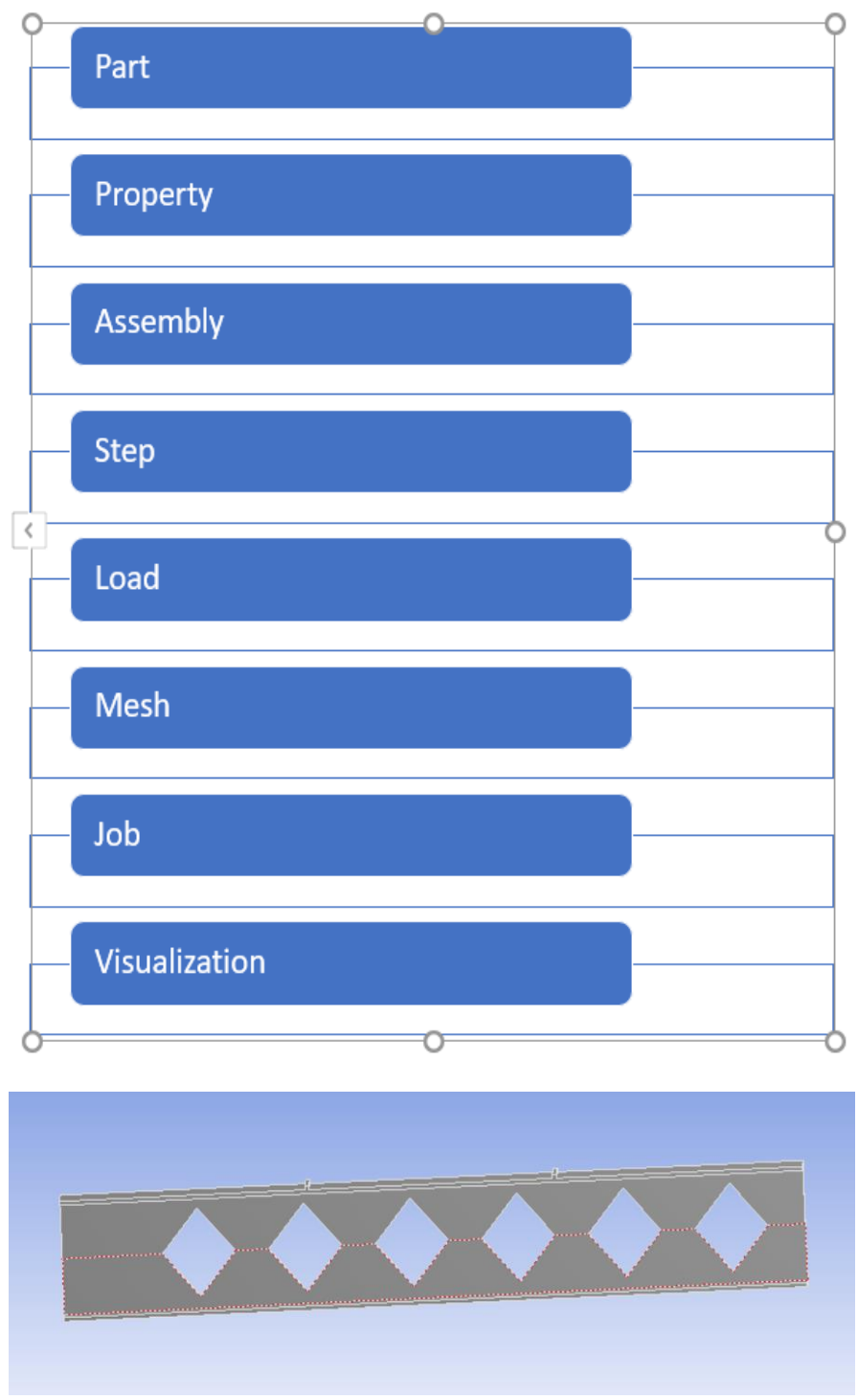

Figure: Beam Geometry in Abaqus

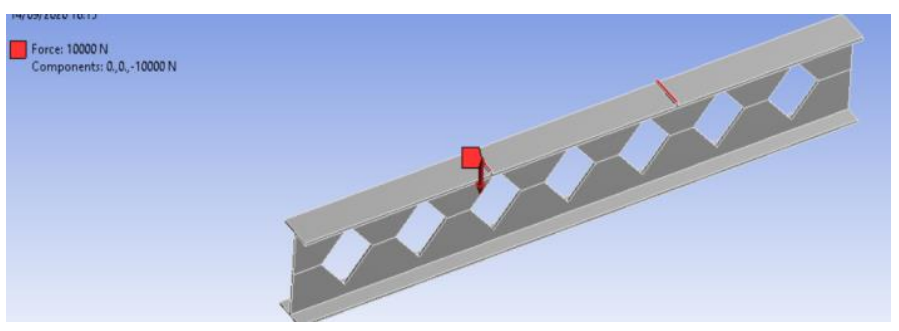

Figure: Load path

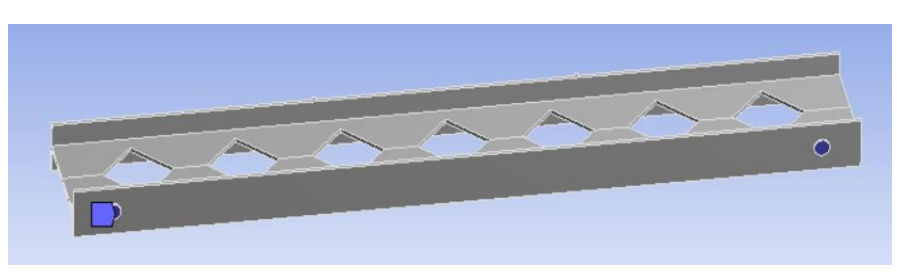

Figure: Support condition

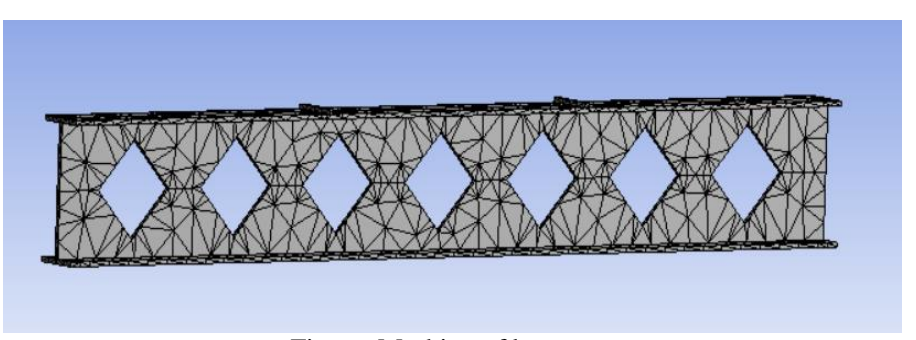

Figure: Meshing of beam

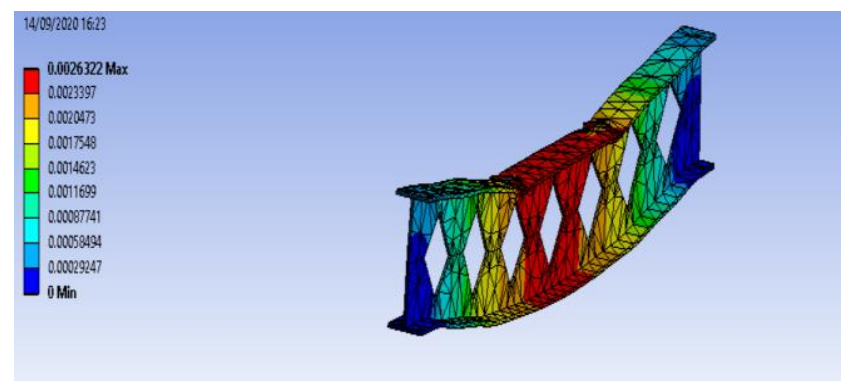

Figure: Sample Results

\section{Result and Discussion}

\begin{tabular}{|c|l|}
\hline LOAD (KN) & $\begin{array}{c}\text { DEFLECTION } \\
(\mathbf{m m})\end{array}$ \\
\hline 5 & 0.216 \\
\hline 10 & 0.440 \\
\hline 15 & 0.665 \\
\hline 20 & 0.933 \\
\hline 25 & 1.07 \\
\hline 30 & 1.19 \\
\hline 35 & 1.21 \\
\hline 40 & 1.226 \\
\hline 45 & 2.25 \\
\hline 50 & 2.30 \\
\hline 55 & 2.45 \\
\hline
\end{tabular}

Table: Load and deflection of castellated beam by using experiment

\begin{tabular}{|c|c|}
\hline LOAD (KN) & DEFLECTION (mm) \\
\hline 5 & 0.225 \\
\hline 10 & 0.450 \\
\hline 15 & 0.675 \\
\hline 20 & 0.900 \\
\hline 25 & 1.12 \\
\hline 30 & 1.13 \\
\hline 35 & 1.15 \\
\hline 40 & 1.18 \\
\hline 45 & 2.20 \\
\hline 50 & 2.22 \\
\hline 55 & 2.24 \\
\hline
\end{tabular}

Table: Load and deflection of castellated beam by using Software

\begin{tabular}{|c|c|c|c|c|}
\hline Sr.no & $\begin{array}{c}\text { Deflection by } \\
\text { software } \\
\text { method in } \mathrm{mm}\end{array}$ & $\begin{array}{c}\text { Deflection by } \\
\text { experiment } \\
\text { method in } \mathrm{mm}\end{array}$ & $\begin{array}{c}\text { Difference in } \\
\text { deflection in } \\
\mathrm{mm}\end{array}$ & $\begin{array}{c}\% \\
\text { Error }\end{array}$ \\
\hline 1 & 0.225 & 0.216 & 0.009 & 4 \\
\hline 2 & 0.900 & 0.933 & 0.033 & 3.66 \\
\hline 3 & 1.180 & 1.226 & 0.046 & 3.90 \\
\hline
\end{tabular}

Table: Comparison between FEM and laboratory testing results

It shows the comparison between FEM and laboratory testing results. From analysis it is observed results obtained from software are less than results from experimentation. 
Table 6.4: analysis results for optimization of depth

\begin{tabular}{|c|c|c|c|c|c|c|c|}
\hline Sr.no & $\mathrm{D}_{0}$ & $\mathrm{D}$ & $\mathrm{D} / \mathrm{D}_{0}$ & $\mathrm{~S} / \mathrm{D}_{0}$ & $\mathrm{~S}$ & $\mathrm{e}$ & $\begin{array}{c}\text { Stress } \\
\mathrm{N} / \mathrm{mm}^{2}\end{array}$ \\
\hline 1 & 120 & 150 & 1.25 & 1.29 & 154.8 & 45.6 & 235 \\
\hline 2 & 111.11 & 150 & 1.35 & 1.29 & 143.33 & 44.44 & 231 \\
\hline 3 & 103.45 & 150 & 1.45 & 1.29 & 133.45 & 41.38 & 223 \\
\hline 4 & 96.77 & 150 & 1.55 & 1.29 & 124.83 & 38.70 & 303 \\
\hline 5 & 90.90 & 150 & 1.65 & 1.29 & 117.26 & 36.36 & 234 \\
\hline 6 & 85.71 & 150 & 1.75 & 1.29 & 110.56 & 34.28 & 242 \\
\hline
\end{tabular}

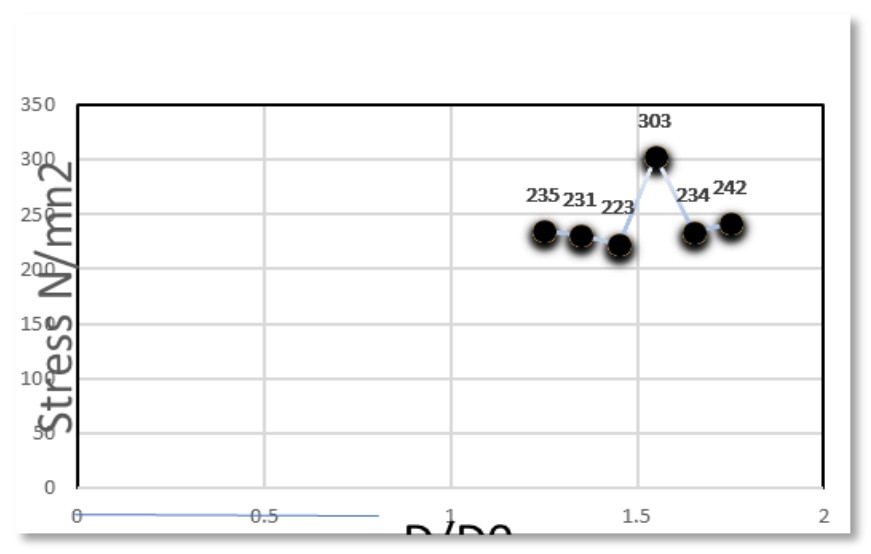

From software result it is found that for D/D0 ratio the value of stress is $235 \mathrm{~N} / \mathrm{mm}^{2}$. Further as D/D0 ratio increases, value of stress also increases the beam whose depth has been optimized, same beam has been taken for optimization of width ie D/D0 ratio equal to 1.45 For optimization After analysis it is observed that D/D0 ratio equal to 1.5 and takes the stress of $223 \mathrm{~N} / \mathrm{mm}^{2}$

\section{CONCLUSIONS}

1.From the software results the buckling of castellated beam for diamond opening is nonlinear. The shape is not uniform 2.Percentage error it is found that experimental results are differed by $3.85 \%$ with software results. This error is within acceptable limit.

3.By varying D/D0 ratio from 1.25 to 1.75 , \% variation of stress is $+2.97 \%$.

4.The optimized D/D0 ratio from above work is 1.45 having stress value $223 \mathrm{~N} / \mathrm{mm}^{2}$

\section{REFERENCES}

[1] A. Jamadar and P. Kumbhar, \Parametric study of castellated beam with circular and diamond shaped openings," International Research Journal of Engineering and Technology, vol. 2, no. 2, pp. 715\{722, 2015.

[2] D. Sonck and J. Belis, ILateral \{torsional buckling resistance of cellular beams," Journal of Constructional Steel Research, vol. 105, pp. $119\{128,2015$.

[3] E. Ellobody, Interaction of buckling modes in castellated steel beams," Journal of Constructional Steel Research, vol. 67, no. 5, pp. $814\{825,2011$.

[4] F. Erdal and M. P. Saka, IUltimate load carrying capacity of optimally designed steel cellular beams," Journal of constructional steel research, vol. 80 , pp. $355\{368,2013$.

[5] J. Yost, D. Dinehart, R. Ho man, S. Gross, and M. Callow, Experimental and analytical investigation of service-load stresses in cellular beams," Journal of Engineering Mechanics, vol. 138, no. 8, pp. 953\{962, 2012.

[6] K. D. Tsavdaridis and C. D'Mello, IWeb buckling study of the behaviour and strength of perforated steel beams with different novel web opening shapes," Journal of Constructional Steel Research, vol. 67 , no. 10 , pp. $1605\{1620,2011$.

[7] L. Budi, W. Partono, et al., IOptimization analysis of size and distance of hexagonal hole in castellated steel beams," Procedia engineering, vol. 171 , pp. $1092\{1099,2017$

\section{BIOGRAPHIES}

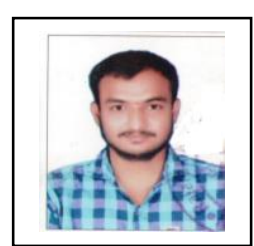

Mr. Guruprasad Dattatray Kulkarni

B.E (Civil) PG student

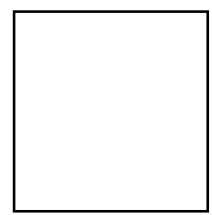

Prof.Rahul. Dattatray Patil

B.E (Civil) MTech Structures Associate Professor at RajaramBapu institute of Technology 